\title{
INTERNATIONAL AND REGIONAL CAPITAL MOBILITY IN LATIN AMERICAN COUNTRIES
}

\author{
Valeryia YERSH (D) \\ Department of Econometrics, Lazarski University, Warsaw, Poland
}

Received 23 March 2021; accepted 22 September 2021; first published online 12 January 2022

\begin{abstract}
This study examines the role of global, regional and domestic saving for domestic investment financing in the panel of Latin American and Caribbean countries along with its three regional integration blocks, namely SICA, Andean Community and MERCOSUR. Panel regression and rolling-window estimation results reveal that global saving is the main source of domestic investment financing in the region of Latin America and the Caribbean, SICA, Andean Community and MERCOSUR. The role of domestic and regional savings is rather limited, implying that there are weak regional and domestic channels that can funnel domestic and regional savings into investment in the analysed samples. The importance of regional agreement saving is insignificant and decreases over the analysed period except for the Andean Community. The results indicate low financial integration of the member-countries within the three regional trade agreements.
\end{abstract}

Keywords: saving-investment association, regional integration, global saving, Feldstein-Horioka puzzle, capital mobility, cointegration analysis, panel estimation.

JEL Classification: C30, E22, F15, F21, F32, F40.

\section{Introduction}

The theory of the intertemporal current account predicts no correlation between domestic saving and investment under the assumption of perfect capital mobility. In other words, countries can borrow freely from the world pool of saving whereas capital can be moved easily across countries in search of the most productive investment opportunities. The first attempt to utilize the aforementioned theory with the aim of estimating the degree of capital mobility has been undertaken by Feldstein and Horioka (1980). Despite their predictions of increased capital flows resulting from the ongoing financial liberalization, the authors arrive at a perplexing result of a tight relationship between saving and investment close to one; as a result, they conclude that the world's capital mobility is insignificant, and incremental saving tend to be invested domestically.

*Corresponding author. E-mail: valeryia.yersh@gmail.com

Copyright (c) 2022 The Author(s). Published by Vilnius Gediminas Technical University

This is an Open Access article distributed under the terms of the Creative Commons Attribution License (http://creativecommons. org/licenses/by/4.0/), which permits unrestricted use, distribution, and reproduction in any medium, provided the original author and source are credited. 
In the last four decades, many subsequent studies have investigated the validity of the Feldstein-Horioka puzzle and analyzed capital mobility in diverse samples of developed and developing economies ${ }^{1}$. However, few studies have analyzed the association between domestic investment and saving for panels that comprise regionally based trade agreements, e.g., ASEAN, NAFTA, EFTA, etc ${ }^{2}$. and almost no studies have investigated saving-investment relationship for panels of Latin American regional trade agreements, including Andean Community, MERCOSUR, and SICA. Thus, this work contributes to the existing literature by providing a comprehensive analysis of the saving-investment relationship within three regional trade agreements of Latin America and the Caribbean. In addition, sub-period analysis has been conducted to see how the saving-investment relationship has been evolving over the analyzed time period.

Moreover, few studies investigate relative importance of regional versus global saving for financing domestic investment ${ }^{3}$ where regional saving is defined as a pool of saving within one geographical region (e.g., East Asia, North America, Sub-Saharan, etc.). However, no study has analyzed the role of regional versus global saving where regional saving is defined as a pool of saving within one integration block. Therefore, this paper makes another contribution to the extant literature by investigating the importance of regional and global saving in investment financing in the Andean Community, MERCOSUR, and SICA. In doing so, this study provides further evidence on regionalism's role in the integration of capital markets. Presently MERCOSUR and Andean Community (customs unions) and SICA (free trade area) are confronted with a crucial decision about harmonization of their national policies necessary for deeper integration. One of such policies would address the coordination of member-countries' exchange rate regimes. Currently the three integration blocks face three options: mutual currency peg, common currency, or dollarization. The success of the monetary integration is directly dependent upon the degree of capital mobility (Beck, 2019, 2020, 2021; Stoykova, 2021). Thus, it is crucial for the three regional agreements to understand the degree of their member-countries' financial integration within a union, regional and global financial markets (Basnet \& Sharma, 2013; Arestis et al., 2003; Scandizzo, 2003).

Estimation results reveal that global saving is the major source for financing domestic investment in the Latin American and Caribbean region, Andean Community, MERCOSUR, and SICA. The result is later confirmed by the sub-period analysis. The role of domestic and regional savings is rather limited, implying that there are weak regional and domestic channels that can funnel domestic and regional savings into investment in analyzed samples. The importance of regional agreement saving is insignificant and decreases over the analyzed period except for the Andean Community. The results indicate low financial integration of the member-countries within the three regional trade agreements. Furthermore, estimation results indicate a strongly sustainable current account deficit in the Andean Community while the overall sample of 23 Latin American and Caribbean countries, SICA and MERCOSUR are found to have a weakly sustainable current account deficit. And finally, SICA observes a

\footnotetext{
${ }^{1}$ See, for example, Ketenci (2010, 2012), Costantini and Gutierrez (2013), Chen and Shen (2015), Katsimi and Zeoga (2016), Drakos et al. (2017), etc.

${ }^{2}$ For example, see Ketenci (2010, 2013), Wang (2013), etc.

${ }^{3}$ See Boubakri et al. (2012), Kim et al. (2014, 2018).
} 
higher extent of capital mobility in the long run than MERCOSUR and Andean Community. The paper is structured as follows. Section 2 briefly presents a literature review. Econometric methodology and data description are summarized in Section 3. Section 4 is devoted to the report and discussion of the empirical findings along with sub-period analysis. The paper ends with a brief conclusion.

\section{Literature review}

The findings of Feldstein and Horioka (1980) have generated a significant amount of theoretical and empirical literature attempting to resolve the puzzle. Some studies have confirmed the Feldstein-Horioka puzzle (see, Feldstein, 1983; Baxter \& Crucini, 1993; Dooley et al., 1987, etc.), other papers show that high saving-retention arises not due to low capital mobility but rather due to the existence of common macroeconomic factors, including fiscal policies, home bias, country-size effect, exogenous shocks (Roubini, 1988; Golub, 1990; Feldstein, 1994; Gordon \& Bovenberg, 1996; Murphy, 1984; Ho \& Chiu, 2001; Ho, 2003; Giannone \& Lenza, 2009; Chang \& Smith, 2013; Costantini \& Gutierrez, 2013; etc.).

Many papers have focused on developed countries to test the Feldstein-Horioka puzzling results in diverse datasets or by applying different methodology. Some studies reveal high saving-retention estimates, an indicator of low capital mobility (Ketenci, 2010; Di Iorio \& Fachin, 2014; Drakos et al., 2017, 2018; Khan, 2017; Ginama et al., 2018, 2021). In contrast, other empirical works find little evidence in favor of the puzzling saving-investment relationship (Georgopoulos \& Hejazi, 2009; Rao et al., 2010; Kumar \& Rao, 2011; Costantini \& Gutierrez, 2013; Holmes \& Otero, 2016; Katsimi \& Zeoga, 2016; Tursoy \& Faisal, 2019; Pata, 2018; Dash, 2019; Plakandaras et al., 2019).

Even though there is a plethora of empirical studies investigating the Feldstein-Horioka puzzle in advanced economies, there are not many studies dealing with the puzzle in emerging economies, especially Latin American and Caribbean countries. Some studies analyzing East-Asian and African countries have revealed low saving-retention coefficient, contradicting the Feldstein-Horioka puzzle (Narayan, 2005; Guillaumin, 2009; Wang, 2013; Raheem, 2017; Murthy \& Ketenci, 2021), while other papers have found little evidence on increased capital flows (Kim et al., 2007; Mitra, 2017; Kaur \& Sarin, 2018; Patra \& Mohanty, 2020; Yilanci \& Kilci, 2021). A limited number of studies focusing on the degree of international capital mobility in the region of Latin America and the Caribbean have demonstrated low saving-retention coefficient, an indicator of high capital mobility (Murthy, 2009; Rocha, 2009; Kumar, 2015; Cavallo \& Pedemonte, 2016); however, the studies either analyse a limited sample of Latina American and Caribbean countries or employ outdated panel estimation techniques or as in case of Kumar (2015) focus only on one of the Latina American regional integration agreements (MERCOSUR). Thus, this paper contributes to the literature on the Feldstein-Horioka puzzle by analysing the extent of capital flows from both regional and global perspective in three Latin American and Caribbean regional trade agreements: SICA, Andean Community and MERCOSUR.

Another research question related to this paper is investigation of the current account deficit (CAD) sustainability in the Latin American and Caribbean region. Like the literature on the Feldstein-Horioka puzzle, the countries of the Latin American and Caribbean region has 
received little attention in the existing literature. For instance, Chortareas et al. (2004) utilize stationarity tests allowing for non-linearities to investigate if the region's debt is sustainable in twelve countries of Latin America. Their findings support sustainability in most cases. Similarly, Holmes (2006) runs an Augmented Dickey-Fuller (ADF) test for sixteen countries of the Latin American region. The author shows evidence of sustainable current account deficits in 12 countries. The previous findings are confirmed by Donoso and Martin (2014) who employ non-linear unit root techniques to assess sustainability of current account in eighteen countries of Latin America and the Caribbean. The authors find the presence of CAD sustainability in 14 out of 18 countries. The opposite results are obtained by Kalyoncu and Ozturk (2010) who find no evidence in favour of CAD sustainability in six countries; only Peru is found to have a sustainable current account deficit. The extent of current account sustainability in the Latin American and Caribbean region is also analyzed by Dash (2020). To this end, the author analyses if exports and imports series are cointegrated by the means of a pooled mean group (PMG) estimator. Estimation results reveal that the Latin American and Caribbean states are characterized by a weakly sustainable CAD. This study departs from the aforementioned literature on CAD sustainability in that it estimates the extent of current account deficit sustainability using a saving-investment association instead of an exportimport relationship. This approach allows to evaluate the extent of CAD sustainability and the degree of capital flows within the same empirical model.

This paper makes another contribution to the existing literature on Latin American experience of regional and global financial integration. Most of the previous studies utilize various measures to assess the degree of global and regional integration of both advanced and emerging economies. For example, some studies analyse stock data to measure the extent to which developed and developing economies are globally and regionally integrated (e.g., Goldberg \& Delgado, 2001; Edison et al., 2002; Barari, 2004; Jawadi et al., 2009; Coudert et al., 2015). Other studies employ consumption risk sharing models to examine global vs regional integration (e.g., Kim et al., 2004, 2006; Kim \& Lee, 2008). A few studies utilize the relationship between domestic investment and savings to assess the degree of regional vs global financial integration (Boubakri et al., 2012; Kim et al., 2014, 2018; Beck \& Stanek, 2019). Even though there are papers which have examined the saving-retention assosiation in Latina American and Caribbean countries, none of them have measured the extent of global and regional integration. Moreover, there are no studies which examine the degree of regional integration from the perspective of the three Latina American regional integration agreements: Andean Community, MERCOSUR, and SICA.

\section{Model and data}

\subsection{Model specification}

The most widely used and tested model of capital mobility is based on the seminal work of Feldstein and Horioka (1980) who run the following saving-investment regression to assess the extent of capital mobility in sixteen OECD economies:

$$
(I / Y)_{i}=\alpha_{i}+\beta(S / Y)_{i}+\varepsilon_{i}
$$


where $(I / Y)$ and $(S / Y)$ are gross capital formation and gross domestic (national) saving as a share of GDP respectively.

If capital mobility is perfect, one should expect domestic investment to be independent of domestic saving, which implies no relationship between the two variables; in other words, if capital mobility is high, a saving-retention coefficient $\beta$ should be close or equal to zero. However, in a closed economy, domestic investment is equal to domestic saving, which implies perfect correlation between the two variables; in other words, if capital mobility is zero, a saving-retention coefficient $\beta$ should be one.

The saving-retention coefficient $\beta$ also indicates how domestic investment is financed by domestic saving. A high coefficient indicates that domestic investment is largely financed by domestic saving whereas a low coefficient shows that only a small part of domestic investment comes from the pool of domestic saving. The latter also means that domestic investment should be financed by regional or global saving, which implies some degree of regional or international capital mobility.

To account for global and regional savings in a panel of Latina American and Caribbean countries, the original equation is augmented by adding regional and world savings as independent variables:

$$
(I / Y)_{i t}^{D}=\alpha_{i}+\gamma(S / Y)_{i t}^{D}+\delta(S / Y)_{i t}^{R}+\lambda(S / Y)_{t}^{G}+\varepsilon_{i t}
$$

where $(I / Y)^{D}$ is gross domestic investment as a share of GDP, $(S / Y)^{D}$ is gross domestic (national) saving as a share of GDP, $(S / Y)^{R}$ is Latina American and Caribbean regional aggregate saving (excluding own country's saving) as a share of regional aggregate GDP, and $(S / Y)^{G}$ is world aggregate saving (excluding Latina American and Caribbean countries' saving) as a share of global aggregate GDP. $\gamma$ is the usual saving-retention coefficient; the closer $\gamma$ to one is, the lower the capital mobility is. $\delta$ measures the degree to which regional saving finances domestic investment; high $\delta$ coefficient indicates high degree of regional capital mobility. $\lambda$ represents the degree to which global saving finances domestic investment; the higher the $\lambda$ coefficient is, the more intensive global capital mobility is.

As for Andean Community, MERCOSUR and SICA, Eq. (2) is augmented by adding regional trade agreement saving:

$$
(I / Y)_{i t}^{D}=\alpha_{i}+\gamma(S / Y)_{i t}^{D}+\theta(S / Y)_{i t}^{A}+\delta(S / Y)_{t}^{R}+\lambda(S / Y)_{t}^{G}+\varepsilon_{i t},
$$

where $(I / Y)^{D}$ is gross domestic investment as a share of GDP, $(S / Y)^{D}$ is gross domestic (national) saving as a share of GDP, $(S / Y)^{A}$ is regional agreement aggregate saving (excluding own country's saving) as a share of regional agreement aggregate GDP, $(S / Y)^{R}$ is Latina American and Caribbean regional aggregate saving (excluding regional agreement's saving) as a share of regional aggregate GDP, and $(S / Y)^{G}$ is world aggregate saving (excluding Latina American and Caribbean countries' saving) as a share of global aggregate GDP. $\theta$ measures the degree to which domestic investment is financed by regional trade agreement saving; high $\theta$ coefficient indicates high degree of capital mobility among members of the trade agreement. $\gamma, \delta$ and $\lambda$ have the same interpretation as in the previous model. 


\subsection{Data}

The data on annual GDP, investment and saving for 109 countries spanning 1985-2017 has been collected from the World Development Indicators database. The variables are measured in current US dollars. Appendix (Table A1) summarizes information on each individual sample along with its list of countries.

Table 1 reports statistical properties of gross domestic saving and gross domestic investment expressed as a percentage of GDP. In the main panel of 23 countries, the average saving and investment rates are $17.95 \%$ and $21.24 \%$ respectively. Venezuela shows the highest average saving rate of $27.96 \%$ while the lowest average saving rate of $1.17 \%$ is found in El Salvador.

Table 1. Descriptive statistics

\begin{tabular}{|l|c|c|c|c|}
\hline \multirow{2}{*}{ Sample } & \multicolumn{2}{|c|}{ S/Y } & \multicolumn{2}{c|}{ I/Y } \\
\cline { 2 - 5 } & Mean & Standard deviation & Mean & Standard deviation \\
\hline Argentina & 19.76 & 0.03 & 17.61 & 0.02 \\
\hline Bahamas & 25.58 & 0.05 & 27.11 & 0.04 \\
\hline Barbados & 14.78 & 0.08 & 15.75 & 0.05 \\
\hline Belize & 18.77 & 0.12 & 21.78 & 0.04 \\
\hline Bolivia & 14.66 & 0.06 & 16.68 & 0.03 \\
\hline Brazil & 19.86 & 0.04 & 19.4 & 0.02 \\
\hline Chile & 26.41 & 0.03 & 23.52 & 0.03 \\
\hline Colombia & 18.94 & 0.03 & 21.0 & 0.03 \\
\hline Costa Rica & 18.14 & 0.03 & 21.21 & 0.03 \\
\hline Cuba & 10.83 & 0.03 & 13.02 & 0.06 \\
\hline Dominican Republic & 18.05 & 0.04 & 23.31 & 0.03 \\
\hline Ecuador & 22.17 & 0.03 & 23.62 & 0.03 \\
\hline El Salvador & 1.17 & 0.04 & 16.86 & 0.02 \\
\hline Guatemala & 6.66 & 0.03 & 15.93 & 0.03 \\
\hline Guyana & 11.4 & 0.11 & 26.43 & 0.09 \\
\hline Honduras & 11.53 & 0.06 & 25.17 & 0.05 \\
\hline Jamaica & 12.07 & 0.09 & 23.92 & 0.03 \\
\hline Mexico & 22.78 & 0.02 & 22.36 & 0.02 \\
\hline Panama & 25.18 & 0.08 & 32.21 & 0.1 \\
\hline Paraguay & 27.31 & 0.04 & 20.85 & 0.02 \\
\hline Peru & 21.62 & 0.04 & 21.46 & 0.03 \\
\hline Uruguay & 17.2 & 0.03 & 16.71 & 0.03 \\
\hline Venezuela & 27.96 & 0.09 & 22.53 & 0.05 \\
\hline \hline Latin America and the Caribbean & 17.95 & 0.09 & 21.24 & 0.06 \\
\hline Andean Community & 19.35 & 0.05 & 20.69 & 0.04 \\
\hline MERCOSUR & 22.42 & 0.07 & 19.42 & 0.04 \\
\hline SICA & 14.22 & 0.09 & 22.35 & 0.07 \\
\hline & & & & \\
\hline
\end{tabular}


The highest average investment rate of $32.21 \%$ is found in Panama while the lowest average interest rate of $15.75 \%$ is observed in Barbados. In the group of three regional integration agreements, MERCOSUR shows the highest average saving rate of $22.42 \%$ and the lowest average investment rate of $19.42 \%$. Conversely, SICA observes the lowest average saving rate of $14.22 \%$ and the highest average investment rate of $22.35 \%$.

\section{Methodology}

\subsection{Unit root testing}

First, the study checks the variables for stationarity and determines their order of integration. To this end, one unit root test is estimated for the cross-sectionally invariant variables, and two panel unit root tests are employed for the cross-sectionally varying variables. The former includes $\mathrm{Ng}$ and Perron (2001) unit root test which estimates four statistics based upon the GLS detrended data. The null hypothesis is that the series are non-stationary. Panel unit root tests comprise IPS (Im et al., 2003) and CIPS (Pesaran, 2007) tests. IPS test relaxes the assumption of homogeneous coefficients imposed by other first-generation unit root tests by allowing both constant and slope estimators to vary across cross-sectional units. However, the main drawback of IPS test is that it assumes cross-sectional independence of error terms. To resolve this problem, Pesaran (2007) has developed CIPS test which is an augmented version of IPS test.

Table 2 reports the results of $\mathrm{Ng}$ and Perron (2001) unit root tests for the cross-sectionally invariant variables. Table 3 summarizes the results of IPS and CIPS panel unit root tests for the cross-sectionally varying variables. Estimation results reveal that saving and investment series in levels are non-stationary; most of the tests fail to reject the null hypothesis of a unit root. When saving and investment series are first-differenced, the series become stationary. Thus, it can be concluded that the order of integration between the two series is one, I(1).

\subsection{Cointegration analysis}

Following the previous literature on the saving-investment relationship, the ratios of gross domestic saving and investment to GDP are checked for cointegration. The study employs Westerlund's (2007) two panel statistic and two group-mean statistics; the former assume homogeneity of cross-sectional parameters while the latter assume heterogeneity of crosssectional parameters. The findings are presented in Table 4. The results suggest that the null hypothesis of no cointegration is rejected in at least two out of four models. The obtained results confirm the previous findings that the ratios of gross domestic saving and investment to GDP are cointegrated, which means that there exists a long-run relationship between the two series. Additionally, the study checks for cointegration between investment and the various types of saving simultaneously. The results are presented in Appendix (Table A2). The panel cointegration results reveal that there is no cointegration between the variables in all the samples. Thus, only domestic saving is included in the long run cointegrating vector. 
Table 2. Ng-Perron unit root test results

\begin{tabular}{|c|c|c|c|c|}
\hline Variable & MZa & Mzt & MSB & MPTa \\
\hline \multicolumn{5}{|c|}{ Latin America and the Caribbean } \\
\hline$(S / Y)^{G}$ & -3.33 & -0.93 & 0.28 & 7.09 \\
\hline$\Delta(S / Y)^{G}$ & $-15.15^{* * *}$ & $-2.73^{* *}$ & $0.18^{* *}$ & $1.67^{* * *}$ \\
\hline \multicolumn{5}{|c|}{ Andean Community } \\
\hline$(S / Y)^{R}$ & -4.59 & -1.27 & 0.28 & 5.77 \\
\hline$\Delta(S / Y)^{R}$ & $-14.39^{* * *}$ & $-2.62^{* * *}$ & $0.17^{* *}$ & $1.66^{* * *}$ \\
\hline$(S / Y)^{G}$ & -2.27 & -0.72 & 0.31 & 8.63 \\
\hline$\Delta(S / Y)^{G}$ & $-15.37^{* * *}$ & $-2.74^{* *}$ & $0.18^{* *}$ & $1.69^{* * *}$ \\
\hline \multicolumn{5}{|c|}{ MERCOSUR } \\
\hline$(S / Y)^{R}$ & -4.56 & -1.46 & 0.32 & 5.46 \\
\hline$\Delta(S / Y)^{R}$ & $-15.11^{* * *}$ & $-2.67^{* * *}$ & $0.18^{* *}$ & $1.66^{* * *}$ \\
\hline$(S / Y)^{G}$ & -2.27 & -0.72 & 0.32 & 8.63 \\
\hline$\Delta(S / Y)^{G}$ & $-15.37^{* * *}$ & $-2.74^{* * *}$ & $0.18^{* *}$ & $1.7^{* * *}$ \\
\hline \multicolumn{5}{|c|}{ SICA } \\
\hline$(S / Y)^{R}$ & -4.19 & -1.21 & 0.29 & 6.13 \\
\hline$\Delta(S / Y)^{R}$ & $-6.08^{*}$ & $-1.7^{*}$ & 0.28 & $4.15^{*}$ \\
\hline$(S / Y)^{G}$ & -2.27 & -0.72 & 0.32 & 8.63 \\
\hline$\Delta(S / Y)^{G}$ & $-15.37^{* * *}$ & $-2.74^{* * *}$ & $0.18^{* *}$ & $1.7^{* * *}$ \\
\hline
\end{tabular}

Note: ${ }^{* *},{ }^{* *}$ and ${ }^{*}$ denote the significance level of 1,5 and $10 \%$ respectively. Individual intercept and trend are included into each test equation. The number of lags has been determined by Schwartz information criterion (SIC) test.

Table 3. Panel unit root test results

\begin{tabular}{|c|c|c|c|c|}
\hline Variable & $I P S_{\mu}$ & $I P S_{\mu, t}$ & $\operatorname{CIPS}_{\mu}$ & $C I P S_{\mu, t}$ \\
\hline \multicolumn{5}{|c|}{ Latin America and the Caribbean } \\
\hline$(I / Y)^{D}$ & $-5.03^{\star * *}$ & $-4.11^{* * *}$ & $-2.43^{\star * *}$ & -2.54 \\
\hline$\Delta(I / Y)^{D}$ & $-10.26^{\star * *}$ & $-7.63^{\star * *}$ & $-5.35^{\star * *}$ & $-5.39^{* * *}$ \\
\hline$(S / Y)^{D}$ & $-2.64^{* * *}$ & -0.81 & $-2.16^{*}$ & $-2.82^{* * *}$ \\
\hline$\Delta(S / Y)^{D}$ & $-8.05^{\star * *}$ & $-5.43^{\star * *}$ & $-5.71^{\star \star \star}$ & $-5.81^{\star * *}$ \\
\hline$(S / Y)^{R}$ & $-2.57^{\star * *}$ & 1.16 & $-2.33^{\star *}$ & $-2.89^{* * *}$ \\
\hline$\Delta(S / Y)^{R}$ & $-5.94^{\star * *}$ & $-2.73^{\star * *}$ & $-5.64^{\star * \star}$ & $-5.68^{* * *}$ \\
\hline \multicolumn{5}{|c|}{ Andean Community } \\
\hline$(I / Y)^{D}$ & $-1.73^{\star \star}$ & $-1.59^{*}$ & $-2.40^{\star *}$ & -2.59 \\
\hline$\Delta(I / Y)^{D}$ & $-3.64^{\star * *}$ & -2.51 & $-5.29^{\star * *}$ & $-5.25^{\star * *}$ \\
\hline$(S / Y)^{D}$ & -0.48 & -0.74 & -2.16 & $-2.99^{* *}$ \\
\hline$\Delta(S / Y)^{D}$ & $-2.53^{\star * *}$ & -1.15 & $-5.39^{\star * *}$ & $-5.45^{\star * *}$ \\
\hline$(S / Y)^{A}$ & -1.25 & -0.67 & -1.65 & $-3.38^{\star * *}$ \\
\hline$\Delta(S / Y)^{A}$ & $-1.96^{\star *}$ & -0.79 & $-5.72^{\star \star \star}$ & $-5.77^{\star * *}$ \\
\hline
\end{tabular}


End of Table 3

\begin{tabular}{|c|c|c|c|c|}
\hline Variable & $I P S_{\mu}$ & $I P S_{\mu, t}$ & $\operatorname{CIPS}_{\mu}$ & $C I P S_{\mu, t}$ \\
\hline \multicolumn{5}{|c|}{ MERCOSUR } \\
\hline$(I / Y)^{D}$ & $-2.25^{\star \star}$ & $-2.07^{\star \star}$ & $-2.56^{* * *}$ & -2.55 \\
\hline$\Delta(I / Y)^{D}$ & $-4.45^{\star * *}$ & $-2.96^{* * *}$ & $-5.73^{* * *}$ & $-5.87^{\star * *}$ \\
\hline$(S / Y)^{D}$ & -0.69 & 0.71 & $-2.45^{\star \star}$ & -2.67 \\
\hline$\Delta(S / Y)^{D}$ & $-4.82^{\star * *}$ & $-3.75^{\star * *}$ & $-5.44^{* * *}$ & $-5.45^{\star * *}$ \\
\hline$(S / Y)^{A}$ & $-2.14^{\star *}$ & -0.47 & -0.62 & -0.88 \\
\hline$\Delta(S / Y)^{A}$ & $-4.49^{\star * *}$ & $-3.06^{* * *}$ & $-4.21^{\star * *}$ & $-4.23^{\star * *}$ \\
\hline \multicolumn{5}{|c|}{ SICA } \\
\hline$(I / Y)^{D}$ & $-2.49^{* * *}$ & $-1.35^{\star}$ & $-2.38^{\star \star}$ & -2.62 \\
\hline$\Delta(I / Y)^{D}$ & $-5.47^{\star * *}$ & $-4.39^{* * *}$ & $-5.24^{\star * *}$ & $-5.37^{\star \star *}$ \\
\hline$(S / Y)^{D}$ & $-1.28^{*}$ & -0.37 & -1.92 & -2.19 \\
\hline$\Delta(S / Y)^{D}$ & $-4.21^{\star * *}$ & $-2.61^{\star * *}$ & $-5.40^{* * *}$ & $-5.58^{\star * *}$ \\
\hline$(S / Y)^{A}$ & 1.97 & 3.56 & -1.63 & -2.30 \\
\hline$\Delta(S / Y)^{A}$ & $-2.56^{* * *}$ & -0.87 & $-5.71^{\star * *}$ & $-5.97^{\star \star \star}$ \\
\hline
\end{tabular}

Note: ${ }^{* *},{ }^{* *}$ and ${ }^{*}$ denote the significance level of 1,5 and $10 \%$ respectively. $\operatorname{IPS}_{\mu}$ and CIPS $_{\mu}$ are panel unit root tests based on a model with an intercept; IPS ${ }_{\mu, t}$ and $C I P S_{\mu, t}$ are panel unit root tests based on a model with an intercept and trend. In each test, the null hypothesis is the presence of a unit root and the alternative hypothesis is the lack of a unit root. $\mathrm{T}^{1 / 3} \approx 3$ is the lag length.

Table 4. Westerlund's cointegration tests results for domestic saving and investment

\begin{tabular}{|c|c|c|c|c|}
\hline Test & Latin America and the Caribbean & Andean Community & MERCOSUR & SICA \\
\hline \multicolumn{5}{|c|}{ Panel statistic } \\
\hline$P_{\tau}$-Statistic & $-3.66^{* * *}$ & -5.06 & $-8.24^{\star *}$ & -5.01 \\
\hline$P_{\alpha}$-Statistic & $-2.46^{\star * *}$ & $-11.82^{\star}$ & $-17 \cdot 10^{\star * *}$ & $-10.81^{\star}$ \\
\hline \multicolumn{5}{|c|}{ Group-mean statistic } \\
\hline$G_{\tau}$-Statistic & $-2.81^{\star *}$ & -2.58 & $-3.17^{\star *}$ & $-2.87^{\star *}$ \\
\hline$G_{\alpha}$-Statistic & $-12.5^{\star * *}$ & $-12.87^{\star * *}$ & $-14.64^{\star *}$ & $-14.34^{\star *}$ \\
\hline
\end{tabular}

Note: ${ }^{* *},{ }^{* *}$ and ${ }^{*}$ denote the significance level of 1,5 and $10 \%$ respectively. $P_{\tau}, P_{\alpha}, G_{\tau}$, and $G_{\alpha}$ are Westerlund's (2007) tests for cointegration; individual intercept and trend are included into each test equation. Robust standard errors have been used.

\subsection{Panel estimation}

Given the results above, the following error-correction framework based on the panel ARDL $\left(p, q_{1}, q_{2}, q_{3}\right)$ is specified for Latin America and the Caribbean:

$$
\begin{aligned}
\Delta(I / Y)_{i t}^{D}= & \sum_{j=1}^{p-1} \omega_{j}^{i} \Delta(I / Y)_{i, t-j}^{D}+\sum_{j=0}^{q_{1}-1} \gamma_{j}^{i} \Delta(S / Y)_{i, t-j}^{D}+\sum_{j=0}^{q_{2}-1} \delta_{j}^{i} \Delta(S / Y)_{i, t-j}^{R}+ \\
& \sum_{j=0}^{q_{3}-1} \lambda_{j}^{i} \Delta(S / Y)_{t-j}^{G}+\varphi^{i}\left[(I / Y)_{i, t-1}^{D}-\beta_{0}^{i}-\beta_{1}^{i}(S / Y)_{i, t-1}^{D}\right]+\varepsilon_{i t} ;
\end{aligned}
$$


and the next error-correction framework based on the panel ARDL $\left(p, q_{1}, q_{2}, q_{3}, q_{4}\right)$ is specified for the Andean Community, MERCOSUR and SICA:

$$
\begin{aligned}
\Delta(I / Y)_{i t}^{D}= & \sum_{j=1}^{p-1} \omega_{j}^{i} \Delta(I / Y)_{i, t-j}^{D}+\sum_{j=0}^{q_{1}-1} \gamma_{j}^{i} \Delta(S / Y)_{i, t-j}^{D}+\sum_{j=0}^{q_{2}-1} \theta_{j}^{i} \Delta(S / Y)_{i, t-j}^{A}+\sum_{j=0}^{q_{3}-1} \delta_{j}^{i} \Delta(S / Y)_{t-j}^{R}+ \\
& \sum_{j=0}^{q_{4}-1} \lambda_{j}^{i} \Delta(S / Y)_{t-j}^{G}+\varphi^{i}\left[(I / Y)_{i, t-1}^{D}-\beta_{0}^{i}-\beta_{1}^{i}(S / Y)_{i, t-1}^{D}\right]+\varepsilon_{i t} .
\end{aligned}
$$

$\gamma, \theta, \delta, \lambda$ represents the degree to which domestic investment financing is done via the domestic, regional agreement, regional and global savings channels, respectively. $\beta_{1}$ measures the degree of current account sustainability. If $\beta_{1}=1$, it can be concluded that CAD is strongly sustainable. On the other hand, if $\beta_{1}=0$, it can be concluded that CAD is strongly unsustainable. The values in-between zero and one indicate a weakly sustainable current account. $\varphi$ is the adjustment coefficient showing how fast domestic investment and savings return to the long-run equilibrium. One would expect $\varphi$ to be negative and lie within the bound of $(0,-1)$ if there exists the long-run equilibrium. $\varphi$ measures the extent of capital flows in the long run. In case of high capital mobility, one would expect the imbalance or the gap between domestic investment and saving to remain for a long period of time without reversing immediately to its long-run value of zero; in other words, the coefficient $\varphi$ should be close to zero. In case of low capital mobility, the adjustment mechanism of the current account will have an immediate effect and will resolve any disequilibrium on the domestic financial market in a short time; in other words, the coefficient $\varphi$ should be be equal or close to negative one. The optimal lag length for the ARDL model can be chosen using one of the consistent information criteria, such as Akaike Information Criterion or Bayesian Information Criterion. However, Dash (2020) recommends imposing a common lag structure to make coefficients comparable across countries. Hence, this study imposes a common lag of 1 for investment and saving series to construct the ARDL model.

Equation 4 and 5 can be estimated using three different approaches. At one extreme, the model can be estimated using a dynamic fixed effects (FE) estimator, which constrains the error-correction, short-run and long-run coefficients to be equal across countries and allows only for country-specific intercepts. However, if the coefficients are not equal, the DFE estimator will produce inconsistent results. At the other extreme, Pesaran and Smith (1995) has proposed a mean group (MG) estimator which estimates a model for each country and calculates arithmetic means of the parameters. The MG estimator allows the error variances, intercepts, error-correction, short-run and long-run coefficients to vary across panels. Pesaran et al. (1997, 1999) have developed an intermediate estimator - pooled mean group (PMG) estimator, which combines both pooling and averaging. The PMG allows error variances, intercepts, error-correction terms and short-run coefficients to differ across countries whereas it imposes the equality of the long-run coefficients. The PMG estimator involves two estimation steps. First, the homogeneous long-run coefficient is obtained using the technique of maximum likelihood. Second, the same technique is employed to estimate heterogeneous error variances, intercepts, adjustment and short-run coefficients.

If the long-run restrictions are correctly imposed, the PMG estimator shows efficiency and consistency in parameter estimation while the MG estimator maintains only consistency. 
However, if the true long-run estimates are different across countries, the PMG estimator loses its consistency while the MG estimation method will still produce consistent longrun parameters. Pesaran et al. (1999) and Dash (2020) argue that homogeneity of the longrun coefficients is a valid assumption since the long-run equilibrium is expected to be the same across cross-sections whereas error-correction terms and short-run estimates depend on country-specific economic conditions and shocks. Additionally, this study employs the Hausman test to check whether the long-run homogeneity assumption is valid. The null hypothesis is the equality of the long-run coefficients across cross-sections and, consequently, the PMG estimator is preferred to the MG estimator; the alternative hypothesis is that the long-run coefficients are country-specific and, consequently, the MG estimator should be chosen over the PMG estimator.

\section{Empirical results}

\subsection{Panel estimation results}

Table 5 reports estimation results of panel error correction models, namely, PMG, MG, and DFE, along with the Hausman test results. Theoretically, the PMG estimator is preferred to MG and DFE estimators. Moreover, the estimated Hausman test statistics imply that the null hypothesis cannot be rejected in all sample, expect for the Andean Community where the data fails to meet the asymptotic assumptions of the Hausman test. Thus, only PMG estimation results are interpreted. The results of DFE and MG estimators are presented for comparison reasons.

In the overall sample of Latin American and Caribbean countries, the coefficients on regional (0.213) and global (0.786) saving are statistically significant. Obtained results suggest that global and regional saving are the main source of investment financing in the analyzed sample, with a dominant role of global saving whereas domestic saving play no significant role in that region.

Similar results are obtained for the Andean Community. The coefficients on regional (0.114) and global saving (1.035) are statistically significant. The results suggest that the two types of saving are essential in investment financing in the Andean Community, with a higher importance of global saving. The coefficient on domestic saving is statistically insignificant whereas the coefficient on integration block saving is negative and statistically significant only at $10 \%$ level. The estimates imply that the role of domestic and integration block saving is rather limited. Hence, estimation results indicate a high degree of financial integration of the Andean Community member states within regional and global capital markets, and a low degree of financial integration within customs union capital market.

Similarly, MERCOSUR shows high and statistically significant coefficients on regional and global savings of 0.241 and 0.768 , respectively. Conversely, domestic and regional agreement savings play no significant role in investment financing in the member states. Estimation results imply a high level of financial integration of MERCOSUR member-countries within regional and global capital markets.

In SICA, the estimated coefficients suggest that domestic, regional and global savings are the main source of investment financing, with a dominant role of global saving. The coefficient on regional agreement saving is estimated to be statistically significant; however, it comes 
with a negative sign, suggesting its low importance in financing domestic investment in SICA member-states.

Table 5 also reports long-run estimates which represent the degree of CAD sustainability in analyzed samples. The coefficients are estimated to be statistically significant, implying that all the four analyzed samples satisfy their long-run solvency constraint. The Wald statistic rejects the null hypothesis that the long-run coefficient is equal to one in the main panel of Latin American and Caribbean states, SICA and MERCOSUR, suggesting that their current account deficits are "weakly" sustainable. However, the Wald statistic fails to reject the null hypothesis in the Andean Community, suggesting a strongly sustainable CAD in the analyzed sample. Table 5 also present the adjustment coefficients which measure the extent of capital flows in the long run along with the convergence speed of domestic saving and investment to their long-term equilibrium value. The obtained error-correction terms are statistically different from zero and fall within the required range of $[0 ;-1]$. The estimates imply that it takes around 2.5 years for the current account disequilibrium to resolve in MERCOSUR and Andean Community. For the entire panel of 23 Latin American and Caribbean states and SICA, the convergence periods are 3.5 and 4 years respectively. Estimation results reveal that the convergence period is the longest in SICA, suggesting that its member countries are characterized by a relatively higher extent of capital flows in the long run. Reversely, the shortest convergence period is found in the Andean Community and MERCOSUR, implying a relatively low degree of long-run capital mobility within the two customs unions.

The key findings from Table 5 can be summarized as follows. First, estimation results suggest that regional and global savings play the most important role in domestic investment financing whereas the importance of domestic saving is rather limited. Thus, the results provide some evidence in favor of regional and international capital mobility in the Latin American region. The only exception is a group of SICA countries where domestic saving is still one of the major sources of domestic investment financing. Moreover, the results reveal that integration block saving has no significant effect on domestic investment. The results can be interpreted as an indicator of low financial integration of the member-countries within the three regional trade agreements. Second, the long-run coefficients reveal the current account deficit is strongly sustainable only in the Andean Community while it is found to be "weakly" sustainable in the other three analyzed samples: the overall panel of 23 countries, MERCOSUR and SICA. And finally, SICA observes a higher extent of capital flows in the long run than MERCOSUR and Andean Community.

Table 5. Panel error correction estimation results

\begin{tabular}{|l|c|c|c|c|c|c|}
\hline \multirow{2}{*}{ Variable } & \multicolumn{2}{|c|}{ PMG } & \multicolumn{2}{c|}{ MG } & \multicolumn{2}{c|}{ DFE } \\
\cline { 2 - 7 } & Coefficient & S.E. & Coefficient & S.E. & Coefficient & S.E. \\
\hline Latin America and the Caribbean & \multicolumn{5}{|c|}{} \\
\hline Long-run coefficient & $0.184^{* *}$ & 0.049 & $0.385^{* * *}$ & 0.106 & $0.348^{* * *}$ & 0.059 \\
\hline Wald statistic $\left(H_{0}: \beta=1\right)$ & $280.8^{* * *}$ & \multicolumn{2}{|c|}{$33.60^{* * *}$} & \multicolumn{2}{c|}{$119.75^{\star * *}$} \\
\hline Error-correction term & $-0.292^{* * *}$ & 0.029 & $-0.362^{* * *}$ & 0.034 & -0.307 & 0.026 \\
\hline Domestic savings & 0.089 & 0.074 & 0.103 & 0.083 & $0.149^{* * *}$ & 0.031 \\
\hline Regional savings & $0.213^{* * *}$ & 0.072 & $0.235^{* * *}$ & 0.071 & 0.112 & 0.072 \\
\hline
\end{tabular}


End of Table 5

\begin{tabular}{|c|c|c|c|c|c|c|}
\hline \multirow{2}{*}{ Variable } & \multicolumn{2}{|c|}{ PMG } & \multicolumn{2}{|c|}{ MG } & \multicolumn{2}{|c|}{ DFE } \\
\hline & Coefficient & S.E. & Coefficient & S.E. & Coefficient & S.E. \\
\hline Global savings & $0.786^{\star * *}$ & 0.203 & $0.697^{* * *}$ & 0.207 & $0.667^{* * *}$ & 0.222 \\
\hline Intercept & $0.053^{* * *}$ & 0.005 & $0.063^{* * *}$ & 0.011 & $0.046^{\star * *}$ & 0.005 \\
\hline Hausman test & & & \multicolumn{2}{|c|}{$4.03^{* *}$} & & \\
\hline $\mathrm{N}$ of countries & \multicolumn{2}{|c|}{23} & \multicolumn{2}{|c|}{23} & \multicolumn{2}{|c|}{23} \\
\hline \multicolumn{7}{|l|}{ Andean Community } \\
\hline Long-run coefficient & $0.497^{\star * *}$ & 0.136 & $0.476^{* * *}$ & 0.105 & $0.395^{* * *}$ & 0.127 \\
\hline Wald statistic $\left(H_{0}: \beta=1\right)$ & \multicolumn{2}{|c|}{13.63} & \multicolumn{2}{|c|}{24.70} & \multicolumn{2}{|c|}{22.69} \\
\hline Error-correction term & $-0.346^{* * *}$ & 0.036 & $-0.367^{\star * *}$ & 0.033 & $-0.347^{\star * *}$ & 0.064 \\
\hline Domestic savings & 0.062 & 0.050 & 0.049 & 0.045 & 0.003 & 0.082 \\
\hline$\Delta S^{A}$ & $-0.249^{*}$ & 0.144 & -0.220 & 0.161 & -0.216 & 0.143 \\
\hline Regional savings & $0.114^{\star \star \star}$ & 0.024 & $0.116^{* * *}$ & 0.005 & 0.157 & 0.126 \\
\hline Global savings & $1.035^{\star *}$ & 0.446 & $1.082^{\star \star}$ & 0.480 & $1.113^{* \star *}$ & 0.403 \\
\hline Intercept & $0.039^{\star * *}$ & 0.006 & 0.039 & 0.005 & $0.045^{\star * *}$ & 0.013 \\
\hline Hausman test & & & & & & \\
\hline $\mathrm{N}$ of countries & 4 & & & & 4 & \\
\hline \multicolumn{7}{|l|}{ MERCOSUR } \\
\hline Long-run coefficient & $-0.213^{\star * \star}$ & 0.062 & 0.293 & 0.267 & $0.222^{* *}$ & 0.106 \\
\hline Wald statistic $\left(H_{0}: \beta=1\right)$ & \multicolumn{2}{|c|}{$378.39^{* * *}$} & \multicolumn{2}{|c|}{6.99} & \multicolumn{2}{|c|}{$53.46^{\star * *}$} \\
\hline Error-correction term & $-0.375^{\star *}$ & 0.158 & $-0.476^{\star \star \star}$ & 0.129 & $-0.413^{* * *}$ & 0.059 \\
\hline Domestic savings & -0.054 & 0.224 & -0.053 & 0.218 & $-0.145^{\star *}$ & 0.063 \\
\hline$\Delta S^{A}$ & 0.190 & 0.133 & 0.229 & 0.154 & $0.081^{\star \star \star}$ & 0.028 \\
\hline Regional savings & $0.241^{\star}$ & 0.132 & $0.238^{\star}$ & 0.127 & 0.059 & 0.175 \\
\hline Global savings & $0.768^{\star \star}$ & 0.343 & 0.601 & 0.391 & $0.785^{\star \star}$ & 0.372 \\
\hline Intercept & $0.097^{\star *}$ & 0.043 & $0.094^{\star *}$ & 0.045 & 0.059 & 0.015 \\
\hline Hausman test & & & 2. & & & \\
\hline $\mathrm{N}$ of countries & 5 & & & & 5 & \\
\hline \multicolumn{7}{|l|}{ SICA } \\
\hline Long-run coefficient & $0.279^{\star * *}$ & 0.098 & $0.487^{\star * \star}$ & 0.164 & $0.445^{* * *}$ & 0.118 \\
\hline Wald statistic $\left(H_{0}: \beta=1\right)$ & \multicolumn{2}{|c|}{$54.41^{* * *}$} & \multicolumn{2}{|c|}{9.82} & \multicolumn{2}{|c|}{$21.99^{* * *}$} \\
\hline Error-correction term & $-0.266^{* * *}$ & 0.039 & $-0.310^{\star * *}$ & 0.046 & $-0.271^{\star * *}$ & 0.044 \\
\hline Domestic savings & $0.266^{\star \star}$ & 0.119 & $0.296^{\star *}$ & 0.138 & $0.173^{\star * *}$ & 0.059 \\
\hline$\Delta S^{A}$ & $-0.315^{\star * *}$ & 0.116 & $-0.336^{\star * *}$ & 0.093 & $-0.412^{\star \star \star}$ & 0.144 \\
\hline Regional savings & $0.225^{\star}$ & 0.128 & $0.221^{\star *}$ & 0.106 & 0.088 & 0.150 \\
\hline Global savings & $1.033^{\star}$ & 0.532 & $0.921^{*}$ & 0.513 & $1.202^{\star * *}$ & 0.3902 \\
\hline Intercept & 0.048 & 0.006 & 0.048 & 0.012 & 0.045 & 0.009 \\
\hline Hausman test & & & & & & \\
\hline $\mathrm{N}$ of countries & 7 & & trit. & & 7 & \\
\hline
\end{tabular}

Note: ${ }^{* *},{ }^{* *}$ and ${ }^{\star}$ denote the significance level of 1,5 and $10 \%$ respectively. The lag structure is ARDL $(1,1,1,1)$ for Latin America and the Caribbean and ARDL $(1,1,1,1,1)$ for the other samples. Hausman test checks the null hypothesis that the PMG is more efficient than the MG estimator. 


\subsection{Sub-period analysis: rolling-window estimation}

The rolling window estimation technique has been used to analyze how the importance of different types of savings and long-run mobility of capital has been evolving within the analyzed time period. PMG panel estimator has been utilized to estimate 20 -year rolling window regressions for the entire panel including 23 Latin American and Caribbean states, and three integration blocks: SICA, Andean Community and MERCOSUR. The results are reported in Figure 1. The first panel in Figure 1 reports the results for Latin America and the Caribbean. Estimation results confirm previous findings that global saving is the main factor in financing domestic investment. Its role has significantly increased in the second half of the analyzed period and has remained high ever since. Domestic and regional savings remain positive throughout the analyzed period with a coefficient around 0.1 , implying that the role of domestic and regional savings is rather limited. Further, domestic and regional savings are substitutes for each other: in the periods when the role of domestic savings has been decreasing, the role of regional savings has been increasing and vice versa.

For the Andean Community, global saving is the main source of domestic investment financing. Despite a gradual decrease over time, the role of global saving has remained high around the value of 1 . Similar to Latin America and the Caribbean, domestic and regional savings remain low throughout the analyzed period. Moreover, domestic and regional savings move in opposite directions, implying a substituting effect between the two types of savings. Regional agreement savings has gradually increased over time into positive territory, suggesting a relative increase in the role of regional agreement savings for financing domestic investment. For MERCOSUR, the role of global saving has increased over time and suppressed that of regional saving. In the second half of the analyzed period, global saving is the main source of domestic investment financing. The role of integration block and regional savings has gradually decreased over time. Further, integration block and regional savings have moved in opposite directions, suggesting a substituting relationship between them. Domestic saving remains around zero, indicating its minimal role in investment financing.

For SICA, the importance of global savings has rapidly increased over time into the positive area. Starting from the second half of the analyzed period, global saving has remained to be the main source of investment financing. Similar to the Andean Community, there is a substituting effect between domestic and regional savings. Even though, both domestic and regional savings remain positive, their role has decreased over time. Regional agreement saving stay in the negative territory and has been decreasing throughout the analyzed period. Overall, the rolling window estimation results confirm previous findings that global saving is the major factor in investment financing in four analyzed samples, implying that Latin American countries' integration within global financial markets is relatively high. Domestic and regional savings remain low and positive, implying that there are weak regional and domestic channels that can funnel domestic and regional savings into investment in analyzed samples. The role of regional agreement saving has decreased over time except for the Andean Community where regional agreement saving has gradually increased over time into positive territory. Domestic and regional savings are found to be substitutes in Latin America and the Caribbean, Andean Community and SICA while there is a substituting relationship between integration block and regional savings in MERCOSUR. 
Latin America and the Caribbean

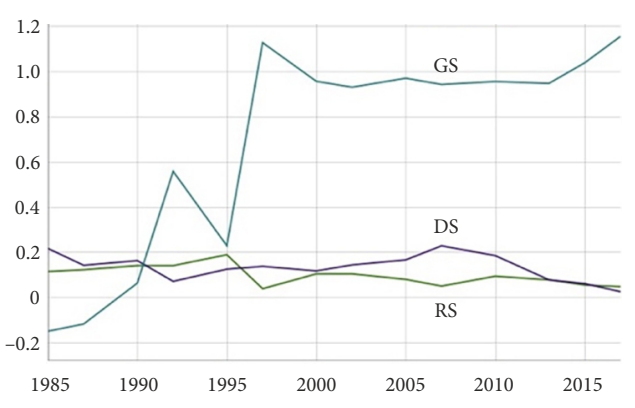

MERCOSUR

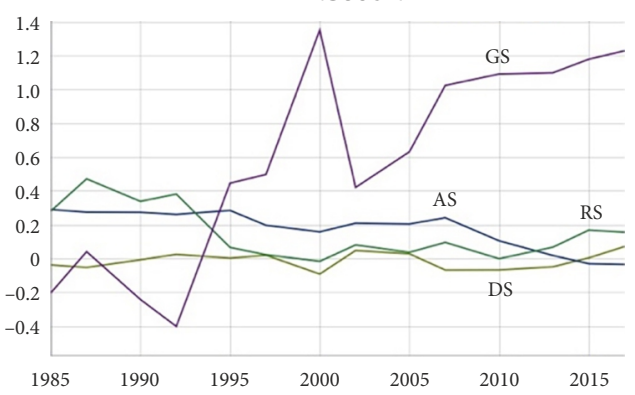

Andean Community

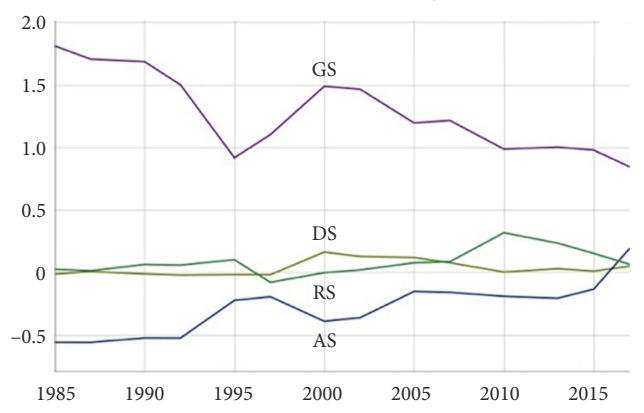

SICA

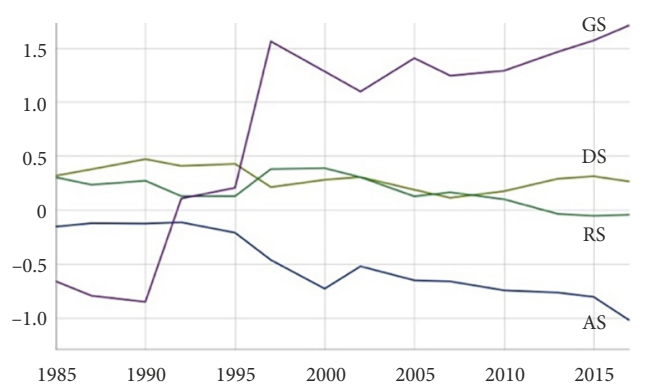

Notes: DS - domestic saving, AS - regional agreement saving, RS - regional saving, GS - global saving. Figure 1. Sub-period analysis

\section{Conclusions}

Considering that the majority of Latin American countries are undergoing the process of monetary integration within one of the three regional trade agreements, it is crucial to understand their level of financial integration within domestic and global capital markets. Thus, this study makes an attempt to analyze the role of regional and global savings in financing domestic investment in the Latin American and Caribbean region, Andean Community, MERCOSUR and SICA.

The results reveal that global saving is the main source for financing domestic investment in Latin American and Caribbean countries along with Andean Community, MERCOSUR and SICA member-states, indicating that Latin American countries are well integrated within global financial markets. The role of regional saving has remained low and positive throughout the analysed period, suggesting that there is a weak regional channel which is capable of funneling regional saving into domestic investment in analyzed samples. Domestic saving is found to be less critical in investment financing in the analysed regions, implying that Latin American countries are less reliant on domestic capital market for financing domestic investment. The results also suggest that the role of integration block saving is rather limited in MERCOSUR and SICA, which can be interpreted as an indicator of low financial integration of the member-countries within the two regional trade agreements. However, the importance of regional agreement saving has been gradually increasing over time in the 
Andean Community and remains around 0.2 at the end of the analysed period, indicating that the Andean Community has been relatively successful at promoting financial integration within the union.

The long-run coefficients reveal the current account deficit is strongly sustainable only in the Andean Community while it is found to be weakly sustainable in the other three analyzed samples: the main panel of 23 countries, SICA and MERCOSUR. And finally, the errorcorrection terms reveal that SICA is characterized by a higher degree of long-run capital mobility than MERCOSUR and Andean Community.

Needless to say, the limitation of this research is the absence of the twin deficits in the underlying model. Consequently, the paper doesn't analyze the role of fiscal deficits in inducing current account deficit unsustainability. However, this issue is beyond the scope of the current paper and hopefully will be tackled in future research.

\section{Acknowledgements}

I am grateful to Krzysztof Beck for his suggestions and support.

\section{Disclosure statement}

No potential conflict of interest was reported by the authors.

\section{References}

Arestis, P., Ferrari-Filho, F., Paula, L. F., \& Sawyer, M. (2003). Options for Monetary Integration in the Andean Community. Revista Venezolana de Análisis de Coyuntura, 9(1), 229-252.

Barari, M. (2004). Equity market integration in Latin America: A time-varying integration score analysis. International Review of Financial Analysis, 13(5), 649-668. https://doi.org/10.1016/j.irfa.2004.02.019

Basnet, H., \& Sharma, S. (2013). Economic integration in Latin America. Journal of Economic Integration, 28(4), 551-579. https://doi.org/10.11130/jei.2013.28.4.551

Baxter, M., \& Crucini, M. J. (1993). Explaining saving/investment correlations. American Economic Review, 83(3), 416-436.

Beck, K. (2019). What drives business cycle synchronization? BMA results from the European Union. Baltic Journal of Economics, 19(2), 248-275. https://doi.org/10.1080/1406099X.2019.1652393

Beck, K. (2020). Decoupling after the Crisis: Western and Eastern business cycles in the European Union. Eastern European Economics, 58(1), 68-82. https://doi.org/10.1080/00128775.2019.1656086

Beck, K. (2021). Capital mobility and the synchronization of business cycles: Evidence from the European Union. Review of International Economics, 29(4), 1065-1079. https://doi.org/10.1111/roie.12536

Beck, K., \& Stanek, P. (2019). Globalization or regionalization of stock markets? The case of Central and Eastern European countries. Eastern European Economics, 57(4), 317-330. https://doi.org/10.1080/00128775.2019.1610895

Boubakri, S., Couharde, C., \& Guillaumin, C. (2012). Assessing the financial integration of Central and Eastern European countries with the euro area: Evidence from panel data cointegration tests. International Economics, 131, 105-120. https://doi.org/10.1016/S2110-7017(13)60056-6 
Cavallo, E., \& Pedemonte, M. (2016). The Relationship between National Saving and Investment in Latin America and the Caribbean. Economía, 16(2), 29-53. https://econpapers.repec.org/article/ col000425/014409.htm

Chang, Y., \& Smith, R. T. (2013). Feldstein-Horioka puzzles. European Economic Review, 72, 98-112. https://doi.org/10.1016/j.euroecorev.2014.09.001

Chen, S., \& Shen, C. (2015). Revisiting the Feldstein-Horioka puzzle with regime switching: New evidence from European countries. Economic Modelling, 49, 260-269. https://doi.org/10.1016/j.econmod.2015.03.020

Chortareas, G., Kapetanios, G., \& Uctum, M. (2004). An investigation of current account solvency in Latin America using Non-Linear Non-stationarity Tests. Studies in Nonlinear Dynamics and Econometrics, 8(1), 1-17. https://doi.org/10.2202/1558-3708.1200

Costantini, M., \& Gutierrez, L. (2013). Capital mobility and global factor shocks. Economic Letters, 120(3), 513-515. https://doi.org/doi:10.1016/j.econlet.2013.06.008

Coudert, V., Herve, K., \& Mabille, P. (2015). Internationalization versus regionalization in the emerging stock markets. International Journal of Finance and Economics, 20(1), 16-27. https://doi.org/10.1002/ijfe.1501

Dash, S. (2019). Has the Feldstein-Horioka puzzle waned? Evidence from time series and dynamic panel data analysis. Economic Modelling, 83, 256-269. https://doi.org/10.1016/j.econmod.2019.02.015

Dash, S. (2020). Are current account deficits sustainable? Evidence from dynamic panel data analysis. Journal of Quantitative Economics, 18, 799-823. https://doi.org/10.1007/s40953-020-00195-y

Di Iorio, F., \& Fachin, S. (2014). Savings and investments in the OECD: A panel cointegration study with a new bootstrap test. Empirical Economics, 46(4), 1271-1300. https://doi.org/10.1007/s00181-013-0722-5

Donoso, V., \& Martin, V. (2014). Current account sustainability in Latin America. The Journal of International Trade and Economic Development, 23(5), 735-753. https://doi.org/10.1080/09638199.2013.775322

Dooley, M., Frankel, J., \& Mathieson, D. (1987). International capital mobility: What do saving-investment correlations tell us? Staff Papers - International Monetary Fund, 34(3), 503-530. https://doi.org/10.2307/3867094

Drakos, A. A., Kouretas, G. P., \& Vlamis, P. (2018). Saving, investment and capital mobility in EU member countries: A panel data analysis of the Feldstein-Horioka puzzle. Applied Economics, 50(34-35), 3798-3811. https://doi.org/10.1080/00036846.2018.1436150

Drakos, A. A., Kouretas, G. P., Stavroyiannis, S., \& Zarangas, L. (2017). Is the Feldstein-Horioka puzzle still with us? National saving-investment dynamics and international capital mobility: A panel data analysis across EU member countries. Journal of International Financial Markets, Institutions and Money, 47, 76-88. https://doi.org/10.1016/j.intfin.2016.11.006

Edison, H., Levine, R., Ricci, L., \& Sløk, T. (2002). International financial integration and economic growth. Journal of International Money and Finance, 21(6), 749-776. https://doi.org/10.1016/S0261-5606(02)00021-9

Feldstein, M. (1983). Domestic saving and international capital movements in the long run and the short run. European Economic Review, 21(1-2), 129-151. https://doi.org/10.1016/s0014-2921(83)80012-9

Feldstein, M. (1994). Tax policy and international capital flows. Weltwirtschaftliches Archiv, 130(4), 675-697. https://doi.org/10.1007/bf02707531

Feldstein, M., \& Horioka, C. (1980). Domestic saving and international capital flows. Economic Journal, 90(358), 314-329. https://doi.org/10.2307/2231790

Georgopoulos, G., \& Hejazi, W. (2009). The Feldstein-Horioka puzzle revisited: Is the home-bias much less? International Review of Economics and Finance, 18(2), 341-350.

https://doi.org/10.1016/j.iref.2007.08.004 
Giannone, D., \& Lenza, M. (2009). The Feldstein-Horioka fact. NBER International Seminar on Macroeconomics, 6(1), 103-117. https://doi.org/10.1086/648699

Ginama, I., Hayakawa, K., \& Kanmei, T. (2018). Examining the Feldstein-Horioka puzzle using common factor panels and interval estimation. Japan and the World Economy, 48, 11-21. https://doi.org/10.1016/j.japwor.2018.06.001

Ginama, I., Hayakawa, K., \& Kanmei, T. (2021). Transition of the Feldstein-Horioka puzzle. Journal of Mathematical Finance, 11(1), 123-151. https://doi.org/10.4236/jmf.2021.111006

Goldberg, C., \& Delgado, F. (2001). Financial integration of emerging markets: An analysis of Latin America Versus South Asia using individual stocks. Multinational Finance Journal, 5(4), 259-301. https://doi.org/10.17578/5-4-2

Golub, S. (1990). International capital mobility: Net versus gross stocks and flows. Journal of International Money and Finance, 9(4), 424-439. https://doi.org/10.1016/0261-5606(90)90020-Z

Gordon, R., \& Bovenberg, L. (1996). Why is capital so immobile internationally? Possible explanations and implications for capital income taxation. American Economic Review, 86(5), 1057-1075.

Guillaumin, C. (2009). Financial integration in East Asia: Evidence from panel unit root and panel cointegration tests. Journal of Asian Economics, 20(3), 314-326.

https://doi.org/10.1016/j.asieco.2009.02.002

Ho, T. (2003). The saving retention coefficient and country-size: The Feldstein-Horioka puzzle reconsidered. Journal of Macroeconomics, 25(3), 387-396. https://doi.org/10.1016/S0164-0704(03)00044-2

Ho, T., \& Chiu, R. L. (2001). Country size and investment-saving correlation: A panel threshold error correction model. Eastern Economic Journal, 27(4), 481-490.

Holmes, M. J. (2006). Do Latin American countries have an incentive to default on their external debts? A perspective based on long-run current account behavior. Emerging Markets Finance and Trade, 42(1), 33-49. https://doi.org/10.2753/REE1540-496X420102

Holmes, M. J., \& Otero, J. (2016). A pairwise-based approach to examining the Feldstein-Horioka condition of international capital mobility. Empirical Economics, 50(2), 279-297. https://doi.org/10.1007/s00181-015-0937-8

Im, K. S., Pesaran, H. M., \& Shin, Y. (2003). Testing for unit roots in heterogeneous panels. Journal of Econometrics, 115(1), 53-74. https://doi.org/10.1016/S0304-4076(03)00092-7

Jawadi, F., Million, N., \& Arouri, M. E. (2009). Stock market integration in the Latin American markets: Further evidence from nonlinear modeling. Economics Bulletin, 29(1), 162-168.

Kalyoncu, H., \& Ozturk, I. (2010). Sustainability of current account for Latin America and Caribbean countries. Applied Economics Letters, 17(8), 781-785. https://doi.org/10.1080/13504850802359937

Katsimi, M., \& Zeoga, G. (2016). European integration and the Feldstein-Horioka puzzle. Oxford Bulletin of Economics and Statistics, 78(6), 834-852. https://doi.org/10.1111/obes.12130

Kaur, H., \& Sarin, V. (2018). An evidence of Feldstein-Horioka puzzle in selected Asian economies. International Journal of Business and Globalisation, 21(4), 454-463. https://doi.org/10.1504/IJBG.2018.095761

Ketenci, N. (2010). The Feldstein-Horioka puzzle by groups of OECD members: The panel approach (MPRA Paper No. 25848).

Ketenci, N. (2012). The Feldstein-Horioka puzzle and structural breaks: Evidence from EU members. Economic Modelling, 29(2), 262-270. https://doi.org/10.1016/j.econmod.2011.10.003

Ketenci, N. (2013). The Feldstein-Horioka puzzle in groupings of OECD members: A panel approach. Research in Economics, 67(1), 76-87. https://doi.org/10.1016/j.rie.2012.09.002

Khan, S. (2017). The savings and investment relationship: The Feldstein-Horioka puzzle revisited. Journal of Policy Modeling, 39(2), 324-332. https://doi.org/10.1016/j.jpolmod.2017.02.002 
Kim, S., \& Lee, J. W. (2008). Real and financial integration in East Asia (Working Paper Series on Regional Economic Integration No. 17). Asian Development Bank.

Kim, S., Kim, S., \& Choi, Y. (2014). Financing investment in East Asia: Regional or global savings? Japan and the World Economy, 31, 1-7. https://doi.org/10.1016/j.japwor.2014.04.001

Kim, S., Kim, S., \& Choi, Y. (2018). International capital mobility: Regional versus global perspective. Review of World Economics, 154(1), 157-176. https://doi.org/10.1007/s10290-017-0300-6

Kim, S., Kim, S. H., \& Wang, Y. (2007). Saving, investment and international capital mobility in East Asia. Japan and the World Economy, 19(2), 279-291. https://doi.org/10.1016/j.japwor.2006.05.001

Kim, S., Kim, S., \& Wang, Y. (2004). Regional versus global risk sharing in East Asia. Asian Economic Papers, 3(3), 182-201. https://doi.org/10.1162/1535351054825210

Kim, S., Lee, J. W., \& Shin, K. (2006). Regional and global financial integration in East Asia (Discussion Paper Series 0602). Institute of Economic Research, Korea University.

Kumar, S. (2015). Regional integration, capital mobility and financial intermediation revisited: Application of general to specific method in panel data. Journal of International Financial Markets, Institutions and Money, 36, 1-17. https://doi.org/10.1016/j.intfin.2015.02.008

Kumar, S., \& Rao, B. B. (2011). A time-series approach to the Feldstein-Horioka puzzle with panel data from the OECD countries. The World Economy, 34(3), 473-485. https://doi.org/10.1111/j.1467-9701.2010.01326.x

Mitra, R. (2017). Domestic saving-investment correlation puzzle revisited: A time series analysis for South Africa. Economics Bulletin, 37(2), 1217-1225.

Murphy, R. G. (1984). Capital mobility and the relationship between saving and investment in OECD countries. Journal of International Money and Finance, 3(3), 327-342.

https://doi.org/10.1016/0261-5606(84)90017-2

Murthy, N. V. (2009). The Feldstein-Horioka puzzle in Latin American and Caribbean countries: A panel cointegration analysis. Journal of Economics and Finance, 33(2), 176-188. https://doi.org/10.1007/s12197-008-9051-5

Murthy, V. N. R., \& Ketenci, N. (2021). The Feldstein-Horioka hypothesis for African countries: Evidence from recent panel error-correction modelling. International Journal of Finance and Economics, 26(4), 5762-5774. https://doi.org/10.1002/ijfe.2092

Narayan, P. K. (2005). The saving and investment nexus for China: Evidence from cointegration tests. Applied Economics, 37(17), 1979-1990. https://doi.org/10.1080/00036840500278103

Ng, S., \& Perron, P. (2001). Lag length selection and the construction of unit root tests with good size and power. Econometrica, 69(6), 1529-1554. https://doi.org/10.1111/1468-0262.00256

Pata, U. K. (2018). The Feldstein Horioka puzzle in E7 Countries: Evidence from panel cointegration and asymmetric causality analysis. The Journal of International Trade \& Economic Development, 27(8), 968-984. https://doi.org/10.1080/09638199.2018.1480053

Patra, S. K., \& Mohanty, R. K. (2020). Does the Feldstein-Horioka puzzle exist among South Asian countries? A regime-switching approach. Journal of Public Affairs, 20(3), 1-14. https://doi.org/10.1002/pa.2061

Pesaran, M. H. (2007). A simple panel unit root test in the presence of cross-section dependence. Journal of Applied Econometrics, 22(2), 265-312. https://doi.org/10.1002/jae.951

Pesaran, M. H., Shin, Y., \& Smith, R. P. (1997). Pooled estimation of long-run relationships in dynamic heterogeneous panel (DAE Working Papers Amalgamated Series 9721).

Pesaran, M. H., Shin, Y., \& Smith, R. P. (1999). Pooled mean group estimation of dynamic heterogeneous panels. Journal of the American Statistical Association, 94(446), 621-634.

https://doi.org/10.2307/2670182 
Pesaran, M., \& Smith, R. (1995). Estimating long-run relationships from dynamic heterogeneous panels. Journal of Econometrics, 68(1), 79-113. https://doi.org/10.1016/0304-4076(94)01644-f

Plakandaras, V., Gogas, P., \& Papadimitriou, T. (2019). A re-evaluation of the Feldstein-Horioka puzzle in the Eurozone. Journal of Risk \& Control, 6(1), 19-35.

Raheem, I. D. (2017). More finance or better finance in Feldstein-Horioka puzzle: Evidence from SSA countries. Global Business Review, 18(1), 132-143. https://doi.org/10.1177/0972150916666912

Rao, B. B., Tamazian, A., \& Kumar, S. (2010). Systems GMM estimates of the Feldstein-Horioka puzzle for the OECD countries and tests for structural breaks. Economic Modelling, 27(5), 1269-1273. https://doi.org/10.1016/j.econmod.2010.02.002

Rocha, F. (2009). Heterogeneity, saving-investment dynamics and capital mobility in Latin America. Empirical Economics, 36(3), 611-619. https://doi.org/10.1007/s00181-008-0215-0

Roubini, N. (1988). Current account and budget deficits in an intertemporal model of consumption and taxation smoothing: A solution to the Feldstein-Horioka puzzle? (NBER Working Paper No. 2773). https://doi.org/10.3386/w2773

Scandizzo, S. (2003). Options for monetary integration in the Andean Community. Revista Venezolana de Análisis de Coyuntura, 9(1), 65-105.

Stoykova, O. (2021). How to increase the value of bilateral trade? Currency union versus fixed exchange rate regime. Entrepreneurial Business and Economics Review, 9(2), 21-38. https://doi.org/10.15678/eber.2021.090202

Tursoy, T., \& Faisal, F. (2019). Validity of FH hypothesis in small isolated Island economy: An application of the combined cointegration approach. Asia-Pacific Journal of Accounting \& Economics, 26(4), 478-488. https://doi.org/10.1080/16081625.2017.1284597

Wang, M. (2013). An investigation of the Feldstein-Horioka puzzle for the Association of Southeast Asian Nations Economies. The Australian Economic Review, 46(4), 424-443. https://doi.org/10.1111/1467-8462.12037

Westerlund, J. (2007). Testing for error correction in panel data. Oxford Bulletin of Economics and Statistics, 69(6), 709-748. https://doi.org/doi:10.1111/j.1468-0084.2007.00477.x

Yilanci, V., \& Kilci, E. N. (2021). The Feldstein-Horioka puzzle for the Next Eleven countries: A panel data analysis with Fourier functions. The Journal of International Trade \& Economic Development, 30(3), 341-364. https://doi.org/10.1080/09638199.2021.1879901 


\section{APPENDIX}

Table A1. Sub-samples description

\begin{tabular}{|c|c|c|c|c|}
\hline Sample & $\begin{array}{l}\text { Latin America and } \\
\text { the Caribbean }\end{array}$ & $\begin{array}{l}\text { Andean } \\
\text { Community }\end{array}$ & MERCOSUR & SICA \\
\hline Period & $1985-2017$ & $1985-2017$ & 1985-2017 & $1985-2017$ \\
\hline Countries & $\begin{array}{l}\text { Argentina } \\
\text { Bahamas } \\
\text { Barbados } \\
\text { Belize } \\
\text { Bolivia } \\
\text { Brazil } \\
\text { Chile } \\
\text { Colombia } \\
\text { Costa Rica } \\
\text { Cuba } \\
\text { Dominican Republic } \\
\text { Ecuador } \\
\text { El Salvador } \\
\text { Guatemala } \\
\text { Guyana } \\
\text { Honduras } \\
\text { Jamaica } \\
\text { Mexico } \\
\text { Panama } \\
\text { Paraguay } \\
\text { Peru } \\
\text { Uruguay } \\
\text { Venezuela }\end{array}$ & $\begin{array}{l}\text { Bolivia } \\
\text { Colombia } \\
\text { Ecuador } \\
\text { Peru }\end{array}$ & $\begin{array}{l}\text { Argentina } \\
\text { Brazil } \\
\text { Paraguay } \\
\text { Uruguay } \\
\text { Venezuela }\end{array}$ & $\begin{array}{l}\text { Belize } \\
\text { Costa Rica } \\
\text { Dominican } \\
\text { Republic } \\
\text { El Salvador } \\
\text { Guatemala } \\
\text { Honduras } \\
\text { Panama }\end{array}$ \\
\hline Total $\mathrm{N}$ of countries & 23 & 4 & 5 & 7 \\
\hline
\end{tabular}

Table A2. Westerlund's cointegration tests results

\begin{tabular}{|c|c|c|c|c|}
\hline Test & $\begin{array}{c}\text { Latin America and } \\
\text { the Caribbean }\end{array}$ & $\begin{array}{c}\text { Andean } \\
\text { Community }\end{array}$ & MERCOSUR & SICA \\
\hline \multicolumn{5}{|c|}{ Panel statistic } \\
\hline$P_{\tau}$-Statistic & -9.89 & -4.00 & $-8.43^{* *}$ & -6.03 \\
\hline$P_{\alpha}$-Statistic & -6.14 & -4.41 & $-8.15^{*}$ & -4.50 \\
\hline \multicolumn{5}{|c|}{ Group-mean statistic } \\
\hline$G_{\tau}$-Statistic & -2.48 & -2.33 & -2.57 & -3.02 \\
\hline$G_{\alpha}$-Statistic & -8.04 & -4.69 & -5.95 & -5.23 \\
\hline
\end{tabular}

Notes: ${ }^{* * *},{ }^{* \star}$ and ${ }^{\star}$ denote the significance level of 1,5 and $10 \%$ respectively. individual intercept and trend are included into each test equation. Robust standard errors have been used. 